\title{
Follow-up on High Lead Concentrations in New Decorative Enamel Paints Available in Egypt
}

\author{
Scott Clark ${ }^{1}$, William Menrath ${ }^{1}$, Yehia Zakaria ${ }^{2}$, Amal El-Safty ${ }^{2}$, Sandy M Roda ${ }^{1}$, Caroline Lind ${ }^{1}$, Essam \\ Elsayed $^{2} \&$ Hongying Peng ${ }^{1}$ \\ ${ }^{1}$ Department of Environmental Health, University of Cincinnati, USA \\ ${ }^{2}$ Department of Occupational and Environmental Health, Cairo University, Cairo, Egypt \\ Correspondence: Scott Clark, Department of Environmental Health, University of Cincinnati, USA. E-mail: \\ clarkcs@ucmail.uc.edu
}

Received: October 21, 2013 Accepted: November 15, 2013 Online Published: December 3, 2013

doi:10.5539/ep.v3n1p33 URL: http://dx.doi.org/10.5539/ep.v3n1p33

\begin{abstract}
The average total lead concentration of new enamel household paints in Egypt was previously reported to be the second highest among the seven countries from Africa, Asia and South America that were included in a 2009 publication. The follow up study reported in this paper includes more than twice as many brands (11 versus 4) and samples (45 versus 20 ) as the initial study. Paints from three of the four brands included in the initial study were sampled again to examine possible changes. Paint from the eight brands not examined in the initial study had lower lead concentrations (4,150 ppm average) compared to brands in the initial study, 26,200 ppm resulting in an average concentration of 11,900 ppm in the follow up study. These two averages are 291- and 132-times higher, respectively, than the current U.S. limit of 90 ppm in new paints for consumer use.

Paint lead concentrations in brands/colors manufactured at different times did not exhibit any overall pattern of increase or decrease. The data from the follow up and initial studies were combined using the sample collected more recently for those brand/colors collected twice, resulting in a total of fifty-two (52) samples with an average lead concentration of $14,300 \mathrm{ppm}$. The presence of lead in new paints continues to represent a threat to children and efforts are needed to cease the use of lead compounds in making paints by using readily available substitutes.

In a 1997 report of the analyses of fifteen (15) new paints intended for use on the interior of houses, the median concentration, $370 \mathrm{ppm}$, and the maximum, 19,200 ppm, were much lower than those presented in this report. This is consistent with a statement in the 1997 report that anecdotal evidence that some paint companies may be starting or increasing the production of lead-based paint.
\end{abstract}

\section{Background and Introduction}

In recent years there has been growing world-wide concern as awareness of the continued use of lead $(\mathrm{Pb})$ in new household paint becomes more widespread. Data from paint analyses of new enamel decorative paints in twelve countries (Adebamowo et al., 2007; Clark et al., 2009) show average concentrations ranging between $7,000 \mathrm{ppm}$ and 32,000 ppm total $\mathrm{Pb}$. Most of the brands tested had concentrations exceeding 10,000 ppm in at least one sample, 111 times the current limit in the United States (CPSIA, 2008). Other studies have also reported very high Pb concentrations (e.g. Van Alphen, 1999; Clark et al., 2006, Lin, Peng, Chen, Wu \& Du, 2008; Kumar \& Gottesfeld, 2008; Toxics Link/IPEN, 2009; Ewers et al., 2011; Nganga, Clark \& Weinberg, 2012; Gottesfeld, Kuepouo, Tetsopgang \& Durand, 2013).

Lead poisoning from the former use of leaded paints is a hazard that continues for decades after use of $\mathrm{Pb}$ in the manufacturing of paint has ended. For example, in the United States, after the use of $\mathrm{Pb}$ in paints was banned thirty-five years earlier, significant $\mathrm{Pb}$-based paint hazards still exist in over 20 million housing units as reported by Jacobs et al. (2002). Several studies of existing housing in other countries have found paints that have high $\mathrm{Pb}$ concentrations: in India by Kuruvilla et al. (2004) and in South Africa by Montgomery and Mathee (2005), In China, Lin et al. (2008) reported high concentrations of $\mathrm{Pb}$ in paints on walls, furniture and toys of kindergarten and primary schools. For children, the major $\mathrm{Pb}$ exposure pathway in housing involves ingestion of $\mathrm{Pb}$-contaminated settled dust on floors and window sells (Jacobs et al., 2002). More than one-half of the housing 
units in New Delhi that were examined by Kumar and Clark (2009) had at least one dust $\mathrm{Pb}$ sample that exceeded the USEPA standard for dust lead loading in floor or window sill dust.

Concern from the findings of high $\mathrm{Pb}$ concentrations in new paints resulted in the creation by the United Nations of the Global Alliance for the Elimination of Lead in Paints (UNEP, 2013) involving the United Nations Environment Programme (UNEP) and the World Health Organization (WHO) (UNEP, 2013). With a goal of fostering the elimination of the use of $\mathrm{Pb}$ in new paints the European Union has provided support for the creation of the multi-year Asian Lead Paint Elimination Project directed by IPEN, an international network of non-governmental organizations involving its member organizations in seven Asian countries (IPEN, 2013).

As global awareness of $\mathrm{Pb}$ paint hazards increase it will also become important to conduct follow up studies to determine whether the awareness has resulted in reductions in the $\mathrm{Pb}$ concentrations in new paints. One such country where a follow-up study has occurred is Egypt. The average paint $\mathrm{Pb}$ concentration reported in the initial paint $\mathrm{Pb}$ sampling in Egypt of 26,200 ppm total $\mathrm{Pb}$, second highest of that found in seven countries in Africa as reported from several studies as shown in Table 1. The average concentration of $\mathrm{Pb}$ in the paints from Egypt was also the second highest of those reported for eleven countries in Africa, Asia and South America as reported by Clark et al. (2009).

Table 1. Total $\mathrm{Pb}$ concentrations in new decorative enamel paints from countries in Africa

\begin{tabular}{ccccccc}
\hline Country & $\begin{array}{c}\text { Date of } \\
\text { Study/ } \\
\text { Report }\end{array}$ & $\begin{array}{c}\# \\
\text { Samples }\end{array}$ & $\begin{array}{c}\text { Average } \\
\text { ppm Pb }\end{array}$ & $\begin{array}{c}\text { \% Samples } \\
\text { greater than } 90 \\
\text { ppm lead }\end{array}$ & $\begin{array}{c}\text { \% Samples } \\
\text { greater than 600 } \\
\text { ppm lead }\end{array}$ & $\begin{array}{c}\text { \% Samples greater } \\
\text { than 10,000 ppm } \\
\text { lead }\end{array}$ \\
\hline Cameroon & $2011^{\mathrm{a}}$ & 60 & 22,800 & 67 & 65 & 25 \\
Egypt & $2006^{\mathrm{b}}$ & 20 & 26,200 & 65 & 65 & 45 \\
Kenya & $2012^{\mathrm{c}}$ & 31 & 14,900 & 87 & 81 & 39 \\
Nigeria & $2009^{\mathrm{b}, \mathrm{e}}$ & 25 & 15,800 & 96 & 96 & 44 \\
Nigeria & $2009^{\mathrm{d}, \mathrm{e}}$ & 23 & 37,000 & 100 & 100 & 65 \\
Senegal & $2009^{\mathrm{d}}$ & 21 & 5,870 & 86 & 76 & 28 \\
South & $2009^{\mathrm{d}}$ & 29 & 19,900 & 65 & 62 & 25 \\
Africa & & & & & & 25 \\
Tanzania & $2009^{\mathrm{d}}$ & 20 & 14,500 & 100 & 95 & 25 \\
\hline
\end{tabular}

${ }^{\mathrm{a}}$ Gottesfeld et al. (2013). ${ }^{\mathrm{b}}$ Clark et al. (2009), ${ }^{\mathrm{c}}$ Nganga et al. (2012), ${ }^{\mathrm{d}}$ Toxics Link (2009).

${ }^{\mathrm{e}}$ Samples with average of $15,800 \mathrm{ppm}$ purchased in 2006; those with $37,000 \mathrm{ppm}$ avg. purchased in 2008 . For the four (4) paints of same brand/color included in each survey, the ratio of the average concentrations $(50,000 / 23,000=2.2)$ was about the same as that for all samples in each survey as shown above $(37,000 / 15,800$ $=2.2$ ).

The purpose of this project is to determine if leaded house paints are still available in Egypt and if there is any evidence of changes in the concentration of $\mathrm{Pb}$ in these paints.

\section{Materials and Methods}

\subsection{Sample Collection}

Enamel household paints from retail shops in the Greater Cairo area were analyzed for total $\mathrm{Pb}$ on two occasions, one reported by Clark et al. (2009) and the other presented in this manuscript. Results from the initial analysis of five colors from each of four major brands were included in with data from a total of eleven (11) countries in three continents. The current follow-up study of forty-five (45) new paint samples includes (1): collection of paints from brands not included in the initial study, (2) paints from some colors of these additional brands that were manufactured at different times and (3) repeat sampling of some paints from brands previously analyzed in initial study (Table 2). 
Table 2. Paint samples collected in follow-up study

\begin{tabular}{lcc}
\hline BRANDS & $\#$ & $\#$ \\
& Brands & Samples \\
\hline $\begin{array}{l}\text { 1.Brands included in Follow-Up Study but not in Initial Study } \\
\text { 2. Brands included in Follow-up Study but not in Initial Study and for which some } \\
\text { paints manufactured at two different times were included }\end{array}$ & $2^{\mathrm{a}}$ & 34 \\
3. Brands included in Initial study that were re-sampled in Follow-up & $6^{\mathrm{a}}$ \\
4. Brand/colors included in Initial study that were re-sampled in Follow-up & 11 \\
5. Total number of brands and samples in Follow-up Study (sum of Lines 1 and 3) & 11 & $7^{\mathrm{b}}$ \\
6. Total number of samples of specific brand/colors included in Follow-up Study (Total & 11 & 45 \\
Sample number in line 5 minus Total Sample number in Line 2) & 39 \\
\hline${ }^{\mathrm{a}}$ these samples are included in line 1 above and are thus not part of the Total in line 5. & \\
b these samples are included in line 3 above and thus are not part of the Total in line 5. &
\end{tabular}

A combined data set was also developed using data from both studies but only using a single result for each brand/color combination. If more than one sample was collected of a particular brand/color, the result from the most recent sample was included in the combined data set. The combined data set has a total of fifty-two (52) samples with unique brand/color combinations.

\subsection{Sample Preparation and Analyses}

Each paint sample was thoroughly mixed with a clean single-use stirrer. For each sample a single coat of paint was carefully applied to a clean piece of polycarbonate with an unused clean paint brush that was discarded after use with one sample. In the initial Clark et al. (2009) survey paint samples were applied to unused clean wood. After drying overnight at room temperature, samples were placed in an unused clean plastic bag for delivery to the H \& E Laboratory at the University of Cincinnati. In the H \& E Laboratory, paint samples were carefully removed from the painted surface by means of a clean sharp paint scraper, using care not to remove portions of the substrate. The paint scrapings were extracted with nitric acid and hydrogen peroxide according to the method: Standard Operating Procedures for Lead in Paint by Hotplate or Microwave-based Acid Digestions and Atomic Absorption or Inductively Coupled Plasma Emission Spectroscopy, EPA, PB92-114172, September 1991 (US EPA, 2001). Extracts were analyzed by flame atomic absorption spectroscopy using a Perkin-Elmer 5100 spectrometer.

The H \& E Laboratory was accredited by the American Industrial Hygiene Association (AIHA) as an environmental $\mathrm{Pb}$ laboratory under the National Lead Laboratory Accreditation Program. The laboratory participated in the Environmental Lead Proficiency Analytical Testing (ELPAT) program. Strict quality control procedures were maintained according to the accreditation guidelines. The accreditation program operated by AIHA meets all international program requirements of ISO/IEC 17025 and subsequently ISO/IEC 17011. AIHA is a full member of the International Laboratory Accreditation Cooperation (ILAC).

\section{Results}

Total $\mathrm{Pb}$ concentration data in parts per million (ppm) dry weight were compared by color and paint brand. Results are presented as average, minimum and maximum and percentages exceeding $90 \mathrm{ppm}, 600 \mathrm{ppm}$ and $10,000 \mathrm{ppm}$. Ninety (90) ppm is the current limit for $\mathrm{Pb}$ in decorative paints in the US (CPSIA, 2008), $600 \mathrm{ppm}$ is the former limit in the US (CPSC, 1977) and the current limit in several countries including Brazil (Brazilian Federal Law, 2008) and Singapore (Singapore NEA, 2004) and 10,000 ppm represents a very high concentration. Analysis of results was also by paint brand and date of paint manufacture or purchase.

\subsection{Pb Concentrations of Paints in Follow-up (Current) Survey}

Forty-five (45) paint samples were collected in the follow up survey. For six brand/color combinations two samples from each were collected with different dates of manufacture. Thus there was a resulting thirty-nine (39) brand/colors included in the current survey. 


\subsubsection{Comparison of Results of Samples From Paint Manufactured at Different Dates}

Results from the duplicate samples for these six brand/color combinations (Table 3) are similar. The four samples with the lowest concentrations in the samples manufactured earlier decreased in concentration from the earlier to the later date of manufacture and the two with higher concentrations increased from the earlier to the later date. The average concentration increased from $6,540 \mathrm{ppm}$ to $9,320 \mathrm{ppm}$. The two-sided $p$-value of Wilcoxon two-sample test is 0.69 , which indicates no statistically significant difference in $\mathrm{Pb}$ concentration between samples collected on different dates.

Table 3. Results of $\mathrm{Pb}$ analyses (ppm) of samples of paints of the same brand/color in follow-up study that were manufactured on different dates

\begin{tabular}{llcc}
\hline Brand & Color & $\begin{array}{c}\text { Pb Concentration (ppm) (date of } \\
\text { manufacture) }\end{array}$ & $\begin{array}{c}\text { Pb Concentration (ppm) (date of } \\
\text { manufacture) }\end{array}$ \\
\hline $\mathrm{A}$ & Black & $146(7 / 08)$ & $30.4(10 / 09)$ \\
$\mathrm{A}$ & Blue & $39.8(5 / 08)$ & $26.1(1 / 09)$ \\
$\mathrm{A}$ & Red & $6,080(5 / 08)$ & $10,600(10 / 09)$ \\
$\mathrm{A}$ & White & $13.9(5 / 08)$ & $8.6(9 / 09)$ \\
$\mathrm{A}$ & Yellow & $32,800(5 / 08)$ & $45,200(9 / 09)$ \\
$\mathrm{B}$ & White & $132(9 / 09)$ & $63.6(10 / 09)$ \\
Average & & 6,540 & 9,320 \\
\hline
\end{tabular}

3.1.2 Comparisons of $\mathrm{Pb}$ Concentrations in Paint Brands/Colors in Initial Study that Are Also Included in Follow-up

Seven (7) of the forty-five (45) samples analyzed in the current study were the same brand/color as included in the initial study. The average $\mathrm{Pb}$ concentrations in the samples of the same brand/color that were collected in the two time periods (Table 4) are similar but one sample from one brand decreased substantially while two from the other brand had large increases. The average of these brand/colors in the initial study was 35,100 ppm and $36,900 \mathrm{ppm}$ in the follow-up study. The two-sided p-value of Wilcoxon two-sample test is 1, which indicates no statistically significant difference between the $\mathrm{Pb}$ concentration in these samples collected in the initial and follow-up studies.

Table 4. Comparison of total $\mathrm{Pb}$ concentrations ( $\mathrm{ppm}$ ) in new enamel decorative paints included in both initial and follow-up studies

\begin{tabular}{cccc}
\hline Brand & Color & $\begin{array}{c}\text { Concentration } \\
\text { (ppm) Initial } \\
\text { Study }\end{array}$ & $\begin{array}{c}\text { Concentration } \\
\text { (ppm) Follow-up } \\
\text { Study }\end{array}$ \\
\hline C & Green & 39,000 & 17,000 \\
C & Yellow & 140,000 & 122,000 \\
D & Blue & 106 & 70.9 \\
D & Green & 14,300 & 16,600 \\
D & Red & 5,620 & 9,040 \\
D & White & 46.6 & 60.5 \\
D & Yellow & 46,600 & 110,000 \\
Overall & & 35,100 & 36,900 \\
Average & & & \\
\hline
\end{tabular}




\subsubsection{Distribution of $\mathrm{Pb}$ Concentrations of Samples in Follow-up Study}

For paint samples of the same brand/color manufactured on different dates that were analyzed, results from the most recent sample, as shown in Table 3, are included in the distribution of $\mathrm{Pb}$ concentrations presented in Table 5. Data from a total of thirty-nine (39) samples are presented in Table 5 by brand and $\mathrm{Pb}$ concentration. Three or more samples were analyzed for seven of the eleven brands.

Table 5. Distribution of total $\mathrm{Pb}$ concentration (ppm) in the thirty-nine brand/color combinations of new enamel decorative paints purchased in Egypt in current follow-up survey

\begin{tabular}{cccccccc}
\hline Brand & $\begin{array}{c}\text { Number of } \\
\text { Samples }\end{array}$ & $\begin{array}{c}\text { Average } \\
\text { Parts Per } \\
\text { Million } \\
\text { (ppm) } \\
\text { Lead }\end{array}$ & $\begin{array}{c}\text { Percent of } \\
\text { Samples } \\
\text { Above 90 } \\
\text { ppm Lead }\end{array}$ & $\begin{array}{c}\text { Percent of } \\
\text { Samples } \\
\text { Above 600 } \\
\text { ppm Lead }\end{array}$ & $\begin{array}{c}\text { Percent of } \\
\text { Samples } \\
\text { Above } \\
10,000 \text { ppm } \\
\text { Lead }\end{array}$ & $\begin{array}{c}\text { Minimum, } \\
\text { ppm }\end{array}$ & $\begin{array}{c}\text { Maximum } \\
\text { ppm }\end{array}$ \\
\hline E & 1 (gold) & 35.3 & 0 & 0 & 0 & 35.3 & 35.3 \\
C & 4 & 51,600 & 100 & 100 & 75 & 5,260 & 122,000 \\
F & 4 & 2,590 & 100 & 50 & 0 & 92.5 & 6,790 \\
G & 1 (blue) & 3,110 & 100 & 100 & 0 & 3,110 & 3,110 \\
H & 1 (white) & 93.3 & 100 & 0 & 0 & 93.3 & 93.3 \\
I & 3 & 134 & 100 & 0 & 0 & 101 & 193 \\
A & 8 & 8,750 & 50 & 38 & 38 & 8.6 & 45,200 \\
D & 6 & 22,600 & 67 & 50 & 33 & 60.9 & 110,000 \\
B & 7 & 5,690 & 86 & 86 & 14 & 63,6 & 16,500 \\
J & 3 & 49.2 & 0 & 0 & 0 & 44.1 & 54.3 \\
K & 1 (red) & 272 & 100 & 0 & 0 & 272 & 272 \\
Overall & 39 & 11,900 & 72 & 49 & 23 & 8.6 & 122,000 \\
\hline
\end{tabular}

Overall $72 \%$ of samples exceeded $90 \mathrm{ppm} \mathrm{Pb}$ concentration and $49 \%$ exceeded $600 \mathrm{ppm}$. The average concentration was $11,900 \mathrm{ppm}$. Six of the eleven brands have an average $\mathrm{Pb}$ concentration above 1,000 ppm; four of eleven brands had at least one sample with a very high lead concentration $>10,000 \mathrm{ppm}$. The two brands with the highest average concentrations, 51,600 ppm (Brand C) and 22,600 ppm (Brand D) had maximum lead concentrations: 122,000 ppm and 110,000 ppm, respectively. These two brands were among the four examined in the initial study.

\subsection{Analysis of Combined Results From the Follow up and Initial Studies}

For the thirteen (13) paints shown in Tables 3 and 4 samples that were manufactured on two different dates were analyzed. Statistical analysis presented earlier revealed that results did not vary by date. Therefore, for these paints only the results from the samples that were manufactured more recently were included in the combined sample analysis. The resulting combined data set contains a total of fifty-two (52) samples. The number of 52 paints was determining by adding the 39 samples of specific brands/colors in follow-up study (Table 3 line 5) to the number of samples in initial study, 20, (as indicated in Abstract) minus the seven (7) paints in the intial study that were re-sampled in the follow-up study (Table 3 line 4). These 52 paints are from twelve (12) brands and have an average $\mathrm{Pb}$ concentration of $14,600 \mathrm{ppm}$ (Table 6). Seventy-three percent (73\%) had $\mathrm{Pb}$ concentrations $>90 \mathrm{ppm}$, fifty-three percent $(53 \%)$ were $>600 \mathrm{ppm}$, twenty-seven $(27) \%$ had concentrations $>$ $10,000 \mathrm{ppm}$ and the highest concentration was $122,000 \mathrm{ppm}$. 
Table 6. Distribution by Brand of Total $\mathrm{Pb}$ Concentration (ppm) in Combined Data Set of New Enamel Decorative Paints Purchased in Egypt in Initial and Follow-up Studies

\begin{tabular}{|c|c|c|c|c|c|c|c|}
\hline Brand & $\begin{array}{l}\text { Number } \\
\text { of } \\
\text { Samples }\end{array}$ & $\begin{array}{l}\text { Average } \\
\text { ppm Lead }\end{array}$ & 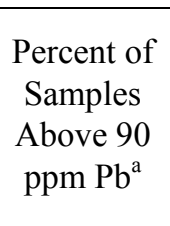 & $\begin{array}{l}\text { Percent of } \\
\text { Samples } \\
\text { Above } \\
600 \mathrm{ppm} \\
\mathrm{Pb}^{\mathrm{b}}\end{array}$ & $\begin{array}{c}\text { Percent of } \\
\text { Samples } \\
\text { Above } \\
10,000 \\
\text { ppm Pb }\end{array}$ & $\begin{array}{l}\text { Minimum, } \\
\text { ppm }\end{array}$ & $\begin{array}{l}\text { Maximum } \\
\text { ppm }\end{array}$ \\
\hline $\mathrm{E}$ & 1 & 35.3 & 0 & 0 & 0 & 35.3 & 35.3 \\
\hline $\mathrm{C}$ & 7 & 37,100 & 86 & 86 & 57 & 4.5 & 122,000 \\
\hline F & 4 & 2,590 & 100 & 50 & 0 & 92,5 & 6,790 \\
\hline $\mathrm{G}$ & 6 & 23,000 & 100 & 100 & 50 & 2,170 & 68,200 \\
\hline $\mathrm{H}$ & 1 & 93.3 & 100 & 0 & 0 & 93.3 & 93.3 \\
\hline I & 3 & 134 & 100 & 0 & 0 & 101 & 193 \\
\hline A & 8 & 8,750 & 50 & 38 & 38 & 8.6 & 45,200 \\
\hline D & 6 & 22,600 & 67 & 50 & 33 & 60.9 & 110,000 \\
\hline B & 7 & 4,990 & 86 & 86 & 14 & 63,6 & 16,500 \\
\hline $\mathrm{J}$ & 3 & 49.2 & 0 & 0 & 0 & 44.1 & 54.3 \\
\hline $\mathrm{L}$ & 5 & 18,100 & 20 & 20 & 20 & 4.5 & 90,600 \\
\hline $\mathrm{K}$ & 1 (red) & 272 & 100 & 0 & 0 & 272 & 272 \\
\hline Overall & 52 & 14,300 & 69 & 48 & 28 & 4.5 & 122,000 \\
\hline
\end{tabular}

${ }^{\text {a }} 90 \mathrm{ppm}$ total $\mathrm{Pb}$ is the current standard in the US for new domestic paints (CPSIA, 2008)

${ }^{\mathrm{b}} 600 \mathrm{ppm}$ total lead is the current standard in several countries including Brazil (Brazilian Federal Law 2008) and Singapore (Singapore NEA, 2004).

The four brands included in the 2009 study (Clark et al., 2009) (C, D, L, and G, as identified in Table 6) had the highest average $\mathrm{Pb}$ concentration in the combined data set, with a range from 18,100 ppm to 37,100 ppm and an average of $26,000 \mathrm{ppm}$. The average concentrations of the eight (8) brands that were included only in the follow up study were lower, ranging from $35.3 \mathrm{ppm}$ and $8,750 \mathrm{ppm}$ with an average of $4,150 \mathrm{ppm}$. The median two-sample test statistic for these data equals 13, and its standardized $\mathbf{Z}$ value is 1.74. The two-sided Chi-Square $\boldsymbol{p}$-value $\mathrm{Pr}>\mathrm{Z}$ equals 0.08 . Although the difference in $\mathrm{Pb}$ concentration between the two groups of paint brands is not significant at the $\boldsymbol{p}$ level of 0.05 , the difference observed may be considered to be of borderline significance.

\section{Discussion}

The lower average $\mathrm{Pb}$ concentration in samples in the follow up study, $11,900 \mathrm{ppm}$, than found in the earlier study, 26,200 ppm, resulted from the lower average concentrations of samples from brands in the follow up that were not included in the earlier study.

For the thirteen paints of various colors of four brands of paint that were collected on two different dates (Tables 3 and 4) the $\mathrm{Pb}$ concentrations were not significantly different between the two sets of samples.

$\mathrm{Pb}$ concentrations in fifteen (15) new interior household paints from Cairo analyzed by Chappell et al. (1997) were much lower than those found in this follow-up study. The concentrations reported by Chappell et al. (1977) ranged from 0.02 to $19,200 \mathrm{ppm}$ and with median $370 \mathrm{ppm}$. The maximum concentration was only about one-sixth of that in this follow up study and one-seventh of that in the earlier study. Five samples in the follow-up study had maximum concentrations higher than that reported by Chappell et al. (1977), ranging from 1.7 times higher to more than six times higher. The median concentration in the follow-up study $(1,690 \mathrm{ppm})$ was 2.8 times higher than that reported by Chappell et al. (1997). These differences may be due to different brands and colors being sampled or to actual increases in the amount of $\mathrm{Pb}$ used in producing paints. Chappell et al. (1997) reported that there was anecdotal evidence, that could not be substantiated, that some private paint manufacturers may be starting or increasing the production of $\mathrm{Pb}$-based paints. 


\section{Conclusions}

Seventy-two (72) percent of the paints in the follow-up study had $\mathrm{Pb}$ concentrations that exceeded the allowable limit in the United States. Forty-nine (49) percent exceeded $600 \mathrm{ppm}$, the former limit in the US and the current limit in some other countries. The average $\mathrm{Pb}$ concentration of $11,900 \mathrm{ppm}$ in the new enamel decorative paints in this follow up study was lower, than the average of $26,200 \mathrm{ppm}$ found in the earlier study. This difference is consistent with the lower average concentrations in samples from brands included in the follow up that were not included in the earlier study

For the thirteen (13) paints of the same brand and color for which samples manufactured on two different dates were analyzed there was no significant difference in the $\mathrm{Pb}$ concentrations over time. This suggests that $\mathrm{Pb}$ concentrations in new paints in Egypt do not appear to be increasing or decreasing with time. Therefore, health authorities and the general public need to be aware of the continuing $\mathrm{Pb}$ threat to children and others from lead-based paints.

Concentrations of lead in new paints in the follow-up and initial studies were much higher those in paints manufactured earlier as reported by Chappell et al. (1997).

\section{References}

Adebamowo, E. O., Clark, C. S., Roda, S., Agbede, O. A., Sridhar, M. K. C., \& Adebamowo, C. A. (2007). Lead Content of Dried Films of Domestic Paint Currently Sold in Nigeria. Science Total Environ, 388, 116-120. http://dx.doi.org/10.1016/j.scitotenv.2007.07.061

Brazilian Federal Law 11.762 is dated August 1, 2008.

Chappell, R., Billig, P., Brantly, E., Ault, S., \& Ezzeldin, H. S. (1997). Lead Exposure Abatement Plan for Egypt: Results of Environmental Sampling for Lead, US. Agency for International Development, USAID Mission to Egypt, Environmental Health Project No. 936-5994, Wash. DC 20523.

Clark, C. S., Rampal, K. G., Thuppil, V., Chen, C. K., Clark, R., \& Roda, S. (2006). The lead content of currently available new residential paint in several Asian countries. Environmental Research, 102, 9-12. http://dx.doi.org/10.1016/j.envres.2005.11.002

Clark, C. S., Rampal, K. G., Thuppil, V., Roda, S. M., Succop, P., Menrath, W., ... Yu, J. (2009). Lead levels in new enamel household paints from Asia. Africa and South America Environmental Research, 109, 930-936. http://dx.doi.org/10.1016/j.envres.2009.07.002 PMid:19656507

Consumer Product Safety Commission (CPSC). 42 Federal Register 44193 (September 1, 1977).

Consumer Product Safety Improvement Act (CPSIA) of 2008, Public Law 110-314, August 11. Washington, DC.

Ewers, L., Clark, C. S., Peng, H., Roda, S. M., Menrath, B, Lind, C., \& Succop, P. (2011). Lead Levels in New Residential Enamel Paints in Taipei, Taiwan and Comparison with Those in Mainland China. Environmental Research, 111(6), 757-760.

Gottesfeld, P., Kuepouo, G., Tetsopgang, S., \& Durand, K. (2013). Lead Concentrations and Labeling of New Paint in Cameroon. Journal of Occupational and Environmental Hygiene, 10, 243-249. http://dx.doi.org/10.1080/15459624.2013.768934 PMid:23472856

IPEN, Asian Lead Paint Elimination Project. Retrieved September 25, 2013, from http://www.ipen.org/projects/asia-project-2012-2015

Jacobs, D. E., Clickner, R. P., Zhou, J. Y., Viet, S. M., Marker, D. A., Rogers, J. W., .. Friedman, W. (2002). The Prevalence of Lead-Based Paint Hazards in US Housing (2002). Environmental Health Perspectives, 110, 599-607. http://dx.doi.org/10.1289/ehp.021100599

Kumar, A., \& Clark, C. S. (2009). Lead Loadings in Household Dust in Delhi, India. Indoor Air, 19, 414-420. http://dx.doi.org/10.1111/j.1600-0668.2009.00605.x PMid:19659889

Kumar, A., \& Gottesfeld. P. (2008). Lead Content in Household Paint in India. Science of the Total Environment, 407, 333-337. http://dx.doi.org/10.1016/j.scitotenv.2008.08.038

Kuruvilla, A., Pillay, V. V., Venkatesh, T., Adhikari, P., Chakrapani, M., Clark, C. S., .. Sinha,S. (2004). Portable Lead Analyzer to Locate Sources of Lead. Indian Journal of Pediatrics, 41, 495-499. http://dx.doi.org/10.1007/BF02724287 
Lin, G. Z., Peng, R. F., Chen, Q., Wu, Z. G., \& Du, L. (2008). Lead in housing paints: an existing source still not taken seriously for children lead poisoning in China. Environmental Research, 109, 1-5. http://dx.doi.org/10.1016/j.envres.2008.09.003

Montgomery, M., \& Mathee, A. (2005). A Preliminary Study of Residential Paint lead Concentrations in Johannesburg. Environmental Research, 98, 279-283. http://dx.doi.org/10.1016/j.envres.2004.10.006 Nganga, C., Clark, S., \& Weinberg, J. (2012). Lead in Kenyan Household Paint, September, 2012, iLima, Nairobi, Kenya, IPEN, University of Cincinnati.

Singapore National Environmental Agency (NEA). (2004). List of controlled hazardous substances. Retrieved June 16, 2004 from http://app.nea.gov.sg/cms/htdocs/article.asp?pid=1428S

Toxics Link-IPEN Global Study: Lead in New Decorative Paints. (2009). Retrieved from $\mathrm{http} / / /$ www.ipen.org/ipenweb/documents/work\%20documents/global_paintstudy.pdf

United Nations Environmental Program (UNEP). (2013). Retrieved September 25, 2013, from http://www.unep.org/hazardoussubstances/hazardoussubstances/LeadCadmium/PrioritiesforAction/GAELP /tabid/6176/Default.aspx

U.S. Environmental Protection Agency (USEPA). (2001). Standard Operating Procedures for Lead in Paint by Hotplate or Microwave-based Acid Digestions and Atomic Absorption or Inductively Coupled Plasma Emission Spectroscopy, EPA, PB92-114172, Sept. 1991

Van Alphen, M. (1999). Lead in Paints and Water in India. In A. M. George (Ed.), Lead Poisoning Prevention \& Treatment: Implementing a National Program in Developing Countries (pp. 265-272). The George Foundation, Bangalore, India.

\section{Copyrights}

Copyright for this article is retained by the author(s), with first publication rights granted to the journal.

This is an open-access article distributed under the terms and conditions of the Creative Commons Attribution license (http://creativecommons.org/licenses/by/3.0/). 